Cahiers $d u$ MONDE RUSSE

\section{Cahiers du monde russe}

Russie - Empire russe - Union soviétique et États indépendants

$61 / 3-4 \mid 2020$

Écritures visuelles, sonores et textuelles de la justice

\title{
Brandon SCHECHTER, The Stuff of Soldiers. A History of the Red Army in World War II through Objects
}

\section{Masha Cerovic}

\section{OpenEdition}

\section{Journals}

Electronic version

URL: https://journals.openedition.org/monderusse/12164

DOI: 10.4000/monderusse.12164

ISSN: $1777-5388$

\section{Publisher}

Éditions de l'EHESS

\section{Printed version}

Date of publication: 1 July 2020

Number of pages: $537-540$

ISBN: 978-2-7132-2832-2

ISSN: $1252-6576$

\section{Electronic reference}

Masha Cerovic, "Brandon SCHECHTER, The Stuff of Soldiers. A History of the Red Army in World War II through Objects", Cahiers du monde russe [Online], 61/3-4 | 2020, Online since 01 July 2020, connection on 14 September 2022. URL: http://journals.openedition.org/monderusse/12164 ; DOI: https://doi.org/ 10.4000/monderusse.12164 


\section{Brandon SCHECHTER}

\section{The Stuff of Soldiers}

\section{A History of the Red Army in World War II through Objects}

Ithaca : Cornell University Press, 2019.

Brandon Schechter's first book, drawn from his $\mathrm{PhD}$ dissertation, offers a beautifully written, sweeping and nuanced history of the Red Army during the Great Patriotic War through the lens of objects and material culture. The Stuff of Soldiers is not only a major contribution to the history of the war; it is also a stimulating attempt to overcome disciplinary boundaries and long-lasting debates about the Soviet project through an ethnographic focus on objects and practices of everyday life.

The Stuff of Soldiers focuses on the soldiers of the Soviet ground forces between 1941 and 1945. It elegantly follows a double narrative arc. The overarching argument traces the transformation of the Red Army from the badly trained, equipped and led army of defeat in 1941, to the victorious professional army of 1945. To do this, the book starts with the soldiers' naked bodies, then goes on to dress, feed, arm, house them, thus turning them in warriors and conquerors, who sowed destruction and reaped loot and trophies. Backed by an in-depth knowledge of the secundary literature in English and Russian, the analysis is based on a broad source base, ranging from official documents, manuals and reports, to diaries and memoirs, including photographic and filmic material and a huge range of oral testimonies collected by various institutions since 1941 .

The method chosen is ethnographic. Brandon Schechter provides a thick description of the soldier's material existence. The book's "stuff" encompasses all of the material world, from the soldiers' bodies to objects, be they clothes, 
tools or possessions. Throughout the book, these "things" exist as both material and symbolic realities. The author gives scant information as to the production or actual history of the objects themselves. His focus is on the ways they are used at the front, and through those uses, on the ways that those objects express and shape the soldiers' actions and feelings, their relations to friend and foe, to state and family, to time and place. Described is a world in constant flux, full of movement and tension, in which the state and the citizen soldiers, men and women from all national and social backgrounds, keep testing, exploring, adjusting, negotiating their mutual needs, duties, rights and the meaning of the ongoing war. Schechter manages to convey the things' inherent ambivalence, both their materiality, heaviness, coarseness, which constrained the soldiers, forced them to adapt their bodies and behaviours, and the versatility, polysemy of their symbolic meanings.

The book is organized in three parts. The first centers on the soldiers' bodies and their needs. After showing how the Soviet state sought to select, discipline and mould soldierly bodies, the author turns to the problems of clothing and feeding them. The chapter on uniforms and medals gives a short but detailed history of the major changes brought by the war, the most famous of which being the return of the officers' epaulets (pogony). Schechter looks at the ways that all actors - decisionmakers, designers, officers, soldiers, civilians - discussed, used and perceived these changes in the outward symbols of military belonging. This examination allows the author to show how the war led to a shift in the collective understanding of historical, social and ethnic relationships, toward a new imperial understanding of Soviet identity - a multiethnic, Russian-dominated entity and political community with deep roots in the past. This first part of the book ends with a fascinating analysis of the challenges arising from the need to feed these soldiers. The book's rich discussion of food weaves multiple questions - the management of soldiers' health through nutrition, the negotiation of religious and cultural differences, the implementation of new social hierarchies through the management of food scarcity in the wartime Soviet Union, the forms and meanings of new habits and rites of collective food consumption in the units. At the heart of the author's questioning is the analysis of food as "paek", a means of exchange and a manifestation of a web of mutual obligations, of rights and duties, binding the state to its citizens, the officers to the soldiers in their charge, as well as civilians to combatants, and the individual with his very private spoon to the collective of comrades in arms sharing the pot, the tobacco and the vodka.

The second part of the book examines the combat experience itself. The author first looks at the front as the central space of experience, a new environment constantly recreated by the soldiers' efforts, their twin never-ending labour of destruction and construction. The discussion is centered on the axe and the spade. Schechter shows how those two key tools allowed the soldiers to build themselves a new world, one of rubbles and trenches, defined and constrained by tactical considerations, but also a "domesticated" social space based on an urban model, one where people were put to the grave by the comrades they had shared so much with - their sleeping space, their meals, but also songs and intimacy in dugholes that 
had become homes, clubs, libraries. The author then discusses the other tool that defined the soldiers, their weapons. The chapter is structured around a twin - individual and collective - process of learning to use them. Every single soldier developped a personal relationship to his or her weapon, as they learned how to kill and avoid getting killed, and the Red Army tried various methods and tactics to get as many of its hastily trained recruits to do so. In the process, the Red Army as a whole also transformed into a professional army, of professional soldiers bound together by strong corporate identites tied to the different arms.

The final part of the book is devoted to the "public-private" world of a soldier's possessions, examining how the soldiers would acquire goods - from letters and lighters to loot and trophies. The discussion examines how different objects could maintain or create private links between the front and the civilians at the rear, within a shared public sphere actively shaped by the state. Revisiting the debates surrounding the treatment of POW's or the widespread looting at the end of the war, the author centers the discussion on the changing and sometimes conflicting values surrounding private property and wealth, as expressed by the state and by the soldiers. By examining how the soldiers treated their own properties and their enemies', the analysis brings into focus one of the main arguments of the book, that the war saw the coalescing of a dominant culture that fused socialist discourse, peasant values and national pride into a specific Soviet construct.

The Stuff of Soldiers is an important addition to the ongoing discussion on what it meant to be Soviet. By focusing on objects rather than on discourse, Schechter offers a nuanced answer, one that emphasizes how ordinary people and the state created a new culture together, without glossing over the tension and ambivalence that remained at the core of a syncretic construct that mostly lacked ideological coherence. Indeed, while Schechter repeatedly emphasizes the importance of shared "socialist" values regarding private property, labour or sacrifice or the role of political officers in the management of morale and discipline, he only gives a marginal role to the Party and to ideological orthodoxy. Conspicuously, one object that does not appear in the book is the party (or komsomol) card (partbilet), in spite of its meanings for communists in uniform.

The book also refines our understanding of the war as a major moment in the history of the revolutionary experiment, beyond the consolidation of a Soviet culture and shared discourse. Some of Schechter's most interesting points arise from his analysis of the ways in which the war was also part of the Soviet experiment in modernization and urbanization. Schechter makes clear that peasants went into the war, but that out the war came modern, technically savvy, well-travelled, urbanized people, with a huge array of diverse cultural experiences, who would never go back to the pre-war village.

One may regret that Schechter is not more explicit when defining who the "soldiers" are that he chose to focus on. One of the book's strengths is, without doubt, the attention paid to a great diversity of experiences and the systematic inclusion of women and ethnic and religious minorities. It is easy to forget who is tacitly excluded from this large and fascinating chorus of Soviet voices. Thus very 
little space is given to officers as subjects (rather than as actors implementing state policies); we mostly see them directing and shaping the soldiers' experience, but hear little about their own experience of the war. At the other end of the military hierarchy, we hear little from all those who never had the time to become members of the professional army that Schechter discusses. The war- and world-weary experts of 1944, with two or three years of front experience, offer the narrative backbone of the book, but were a small minority in the army's ranks. Those were always dominated by barely trained recruits who were mostly cannon fodder, in part, precisely, because of their failure to learn to use their guns, helmets and spoons. Schechter rightly insists on the importance of comradeship and burial rituals in the soldiers' sense of collective identity, without reconciling it with the fact-discussed in detail in chapter 4 - that most soldiers died an anonymous death and were often left with no burial at all, because they did not have any comrades. The Central Asian soldiers who were recruited in 1941 and 1942 and managed to survive may have learned Russian and found their place in the new imperial patriotic discourse, but does that hold true for the recruits from pre-war Poland sent to the front in the last months of the war? Of course, no history can cover the experiences of 35 million Red Army members; nonetheless, one wonders whether the failure to learn to use "the stuff of soldiers" - the lack of skills, of training, of time to bend these misshapen objects into useful tools - may not have been a more dominant experience than the learning process stressed by the proud veterans. Schechter offers a fascinating history of the emergence of a new dominant social group and culture through combat experience, hard-won professional expertise and the sheer luck of survival. This new soldierly elite won the war and in doing so, considerably broadened and redefined popular support for the Stalinist project. 